\title{
Substantial Factors of Construction Management Causes Budget Overrun in Construction Industry of Oman
}

\author{
Qadir Bux alias Imran Latif ${ }^{1 *}$, Raja Khan Mohammed Gopang², Ismai Abdul \\ $\operatorname{Rahman}^{3}$
}

${ }^{1}$ Department of Civil and Environmental Engineering, College of Engineering and Architecture, University of Nizwa, P O Box 33, P C 616, Nizwa, OMAN

${ }^{2,3}$ Faculty of Civil Engineering and Built Environment, Universiti Tun Hussein Onn Malaysia (UTHM), 86400, Parit Raja, MALAYSIA

${ }^{2}$ Senior Project Control Engineer, Riyadh Metro PMCM, Riyadh Metro Project Oruba Site Complex, P O Box 66601, Olaya Disyrict, 11586 Riyadh, SAUDI ARABIA

*Corresponding Author

DOI: https://doi.org/10.30880/ijscet.2020.11.02.024

Received 30 July 2020; Accepted 30 August 2020; Available online 02 September 2020

\begin{abstract}
Construction development industry's principle objective is to guarantee that the schemesfinish on time inside financial plan, and accomplish diverseobjectives. Construction project endsinside spending plan, is basic worries in development the board, and imagined as most significant limitations for estimating achievement of any development venture. Budget overrun can be defined as the actual extra amount that is spenton a project than was planned in the budget. This budget overrun required extra financial expenditure. The root cause factors of budget overrun due to construction management and highlighted with reason and recommendation. The main objective of this study is to clarify the factors that causes budget overrun in construction project at Muscat, Khabourah, Bidbid, Musanah and Sohar cities in Oman. The quantitative analysis is carried out by interviewing construction experts working as consultant, contractors and project client in Oman via questionnaire. The collected data is analyzed by using average index method to determine the substantial factors causing budget overrun in construction projects.
\end{abstract}

Keywords: Construction, Costoverrun, causes, factors, Oman, Management, budget.

\section{Introduction}

Cost is the basic part for any construction development scheme [1]. Notwithstanding, cost overwhelm is seen as one of the most as often as possible happening issues in development projects worldwide [2,3]. These issues should be concentrated more to decrease later on, where these raid once in a while surpasses $100 \%$ of the foreseen cost of the project [4].

Abdul-Aziz Alghonamy, 2015 examined the cost overrun in construction development industry in Mecca city, so as to distinguish the factors for cost overrun through a questionnaire survey using average index analysis. This research was embraced of 43 contract based workers dealing with development company in the Northern Region of Saudi Arabia utilizing to show the outcomes. Researchers found that the most significant components causing cost overrun are 'additional work', 'bid award for lowest price', 'changes in material types and specifications during construction', 
'disputes on site', 'effects of weather', 'fluctuation of prices of materials', 'frequent changes in design', 'lack of adequate manpower', 'lack of contractor experience', 'long period between design and time of implementation' and 'mistakes in design' [5].

R M Johnson and R I I Babu (2018) explained in a research conducted in UAE by using synchronized diversified approach, using a questionnaire and an interview that the top five causes of cost overrun are design variation, poor cost estimation, delay in client's decision making process, financial constraints of client and inappropriate procurement method [6].

Aftab Hameed and Ismail A Rehamn 2013 conducted research to recognize the most substantial factors caused cost overrun in Malaysia by questionnaire survey using Arithmetic Mean method. According to the researchers the critical factors are 'poor site management and supervision', 'schedule delay', 'inadequate planning and scheduling', 'lack of experience', 'inaccurate time and cost estimates', 'mistakes during construction', 'inadequate monitoring and control', 'frequent design changes', 'mistakes and errors in design', 'poor design and delays in design' and 'delay preparation and approval of drawings' [7].

Cost Overrun in Oman: The construction industry accounts for a 9 per cent share of Oman's GDP and is the country's largest employer. Total investment spending is estimated at 3.7 billion Omani riyals in 2019 for infrastructure development, The Oman construction market is expected to register a CAGR of 6\% over the forecast period, 2019-2024. Alike other countries, construction development industry in Oman is additionally confronting a great deal of difficulties, for example, the surpassing of the undertaking financial budget of project. Ali Alnuaimi, and Mohammed Al Mohsin, 2015, indicated this investigation to distinguish different factors liable for development cost overrun. A model review and interviews were done among chosen experienced individual for master supposition to distinguish the critical factors causing cost overrun in Oman [3,9]. The survey retorts were investigated by average indexed method, that conveyed about recognizable proof of 59 basic factors causing construction development cost overrun in Oman. Results show that the most noteworthy factors causing cost overrun are 'poor design', 'delays in design', 'unrealistic contract duration', 'lack of experience', 'late delivery of materials and equipment', 'delay preparation and approval of drawings', 'inadequate planning and scheduling', 'poor site management and supervision' and 'mistakes during construction' [3,9].

T Al Amri and M Marey Perez (2020) investigates the main cost overrun causes in construction projects within Oman related to clients, contractors, and consultants are determined by analysis targeting 100 project managers was conducted to indicate top causes among them. Results shows that cost overrun, the main client-related factors include change of the project's scope. Poor planning and management were established as important contractor-related determinants of project cost overrun. Lastly, poor drawings contributed as a top cause for consultant related cost overrun reasons [8.9].

\section{Methodology}

In this research, organized questionnaire was utilized in the amassing of information. The survey was utilized to gather definite data about respondent's happenstances and impressions about budget overrun. The questionnaire survey review was additionally adjusted to hear input on thoughts of respondents about budget overrun in the Oman construction development industry. A questionnaire structured as per the accompanying phases:

Sources of Data Collection: This analysis is relying much upon essential and discretionary information. Essential information was made up information gathered by the chooses using questionnaires, and site visits perception. The discretionary sources of information were acquired utilizing the previous researches. Fifty-three (53) factors causing budget overrun have been extricated from sources, for example, Material and Equipment used, Labors issue, contractors, client and consultant responsibility and contract management from the literature [1,4,6,10-17].

Design of Questionnaire: The questionnaires were distributed a total of 150 professionals, 135 professionals filled questionnaire were received. It was found that 10 of returned questionnaires were erroneous and excluded from analysis. The collected data of 125 respondents used in analysis based on average index method. Survey is parted into three sections: Demographics, factors causing budget overrun, suggestions and recommendations. In initial segment, fundamental statistics of respondents [3,4]. In second part, factors causing budget overrun on writing contemplates referenced. In third part, respondent endorsements with respect to decrease of budget overrun in construction development are referenced. The factors were utilizing the Likert scale. The respondents were solicited to rank on a scale from 1-5 factors that cause budget overrun where 1 = "Not Important", 2 = "Least Important", 3 = "Imortant", $4=$ "Very Important" and 5 = "Most Important" [2,3].

Data Analysis Method: The noteworthy factors are determined by using average index analysis. Rating Scale is calculated based on average weight of likert scale based on the weight assigned to each factor by each respondent $[2,3]$. The rating normal is determined as follows,

$$
\text { Averagelndex }(A l)=\frac{W_{1} X_{1}+W_{2} X_{2}+W_{3} X_{3}+W_{4} X_{4}+W_{5} X_{5}}{N}
$$


Where $\mathrm{N}=$ Total number of respondents, $\mathrm{W}_{1}=1$ for "Not Important, $\mathrm{W}_{2}=2$ for "Least important", $\mathrm{W}_{3}=3$ for "Important", $\mathrm{W}_{4}=4$ for "Very Important", $\mathrm{W}_{5}=5$ for "Most Important", $\mathrm{X}_{1}=$ No. of respondents of $\mathrm{W}_{1}, \mathrm{X}_{2}=\mathrm{No}_{\text {. of }}$ respondents for $\mathrm{W}_{2}, \mathrm{X}_{3}=$ No. of respondents for $\mathrm{W}_{3}, \mathrm{X}_{4}=$ No. of respondents for $\mathrm{W}_{4}, \mathrm{X}_{5}=$ No. of respondents for $\mathrm{W}_{5}$ $[2,3]$.

\section{Data Characteristics}

A preliminary quantitative study was carried out to identify the most important factors causing budget overrun in construction industry of Oman. Total of Fifty three (53) identified factors causing budget overrun have been extracted from sources such as Material and Equipment used, Labors issue, Contractors, client and consultant responsibility and contract management from the literature (Al- Gahtani and Mohan 2007, Engr. Nashwan Hamid Yahya Al-Emad 2008, Al-Momani, A., (1996)., summarized in a structured questionnaire and distributed to owner, consultant and contractors at wilayat Muscat, Khabourah, Bidbid, Musanah and Sohar in Oman. The questionnaire distribution was done randomly using two approaches, namely via email as well as direct visitations to the respective firms. The purpose of respondent's demography is to review the capabilities of the respondents in understanding the factors causing budget overrun. Fig.4.1 (a) shows the background of the respondents. Based on organization distribution It was found that the majority of the respondents are from clients with highest percentage of $50 \%$ has major influence, followed by contractors, $36 \%$ and remaining $14 \%$ respondent are from consultant.

client

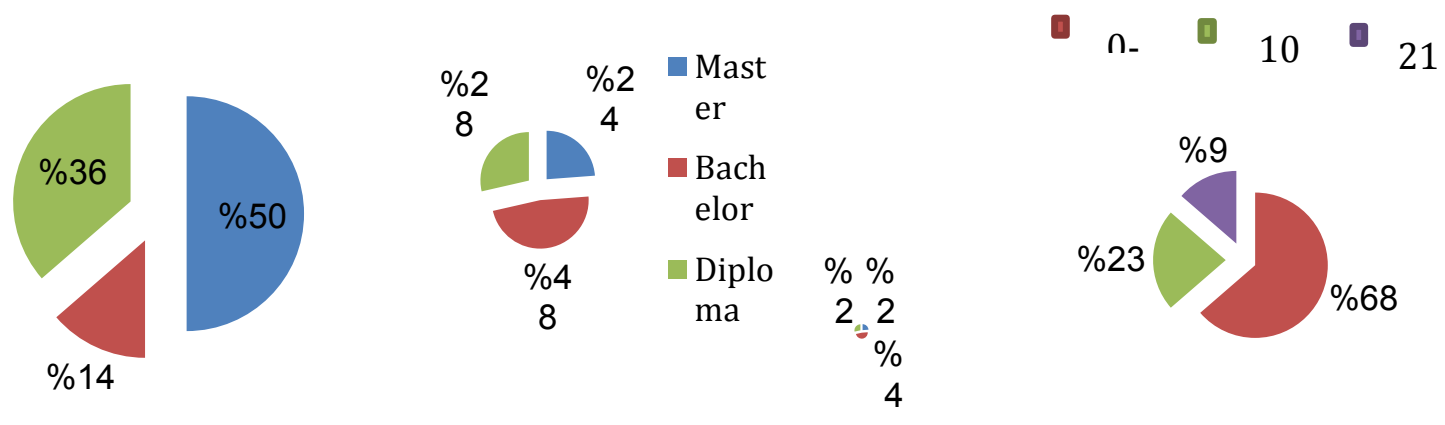

Fig. 4.1 - (a) Organization of respondents; (b) Qualificationof respondents; (c) Experience of respondents

The qualification of the respondents is varying between Bachelor, Masters and Diploma degrees. Figure 4.1 (b) conferring the background of respondent's qualifications. Its show that the highest qualification of the respondents is Bachelor's degree having 48\%, followed by Master's and Diploma degree holder having equal distribution percentage of $24 \%$ respectively.

In term of experience in the construction industry, figure 4.1 (c) found that as much as $68 \%$ of respondents had working experience of 0 to 10 years, followed by $23 \%$ respondents possessed working experience of between 11 to 20 years, and $9 \%$ of respondents had working experience of 21 to 30 years. The minority group of respondents in terms of work experiences was those between 21 t0 30 years' experience, is $9 \%$.

\section{Substantial Factors of Budget Overrun}

To distinguish the substantial factors that causes budget overrun from each source such as material, equipment used, labors issue, contractors, client and consultant responsibility and contract management 53 factors were recognized by reviewing the literature, Table 5.1 underneath illustrate each factor and the relative reactions as to its significance.

Materials: there are 3 substantial factors that contribute in causing budget overrun in construction project, related to materials. In table 5.1 average index analysis indicates that the substantial factors with highest rank are 'fluctuation of prices of construction material', 'quality of material' and 'changes in material specification and type'. Some construction material in Oman is locally available and produced. Mostly finishing material is imported from UAE either UAE made or imported from other countries such India, Europe, UK. Price and quality of construction material varies based on material specification. Consultant and contractors are liable for specification and quality of material used. However, client has to carry the burden of surge in price through contractor. Now a day's fluctuation of price is most common problem due to fluctuation of oil prices around the world. Contractors should give special attention to the following factors, Contractors are recommended to be aware about construction materials, so they are advised to 
purchase the construction materials at the beginning of work. It is also better for them to have time schedule for material delivery process to the site in order to avoid shortage or lack of materials. Contractors are advised to set up stores for required construction materials, and especially those are scarce or that are in limited quantity in the markets and due to fluctuation of price. Pre-construction preparation and smart project management should adopt. Construction industries should start by identifying priced worldwide commodities such as steel and finishing material. Stocking a huge amount of materials earlier starting the construction through a good estimate costing and evaluations before the construction start. Research the availability of and demand for local materials. Outline any special materials required for the project, such as marble or ceramics.

Equipment: The equipment related significant factors are 'High cost of machinery and its maintenance', 'Inadequate modern equipment', and 'Insufficient numbers of equipment'. When the price of equipment is very high it will affect the total budget of the project. A machinery necessitates some other accessories to buy for proper functioning for the distinct chores also causes will increase in the cost of the project.

Labour: Labour related issues are usually interrelated to contractor, and it also can be associated with consultant with respect to experience of skilled labour. The significant factors that contributes in causing budget overrun of the project are 'Severe overtime', 'Shortage of skilled site workers', and 'High cost of skilled labors'. If there is lack of site labors the construction of the project will not be completed on time within budget until unless workers have to do more than the specified works so it will increase the budget and will have budget overrun. Furthermore, contractors always prefer to hire ordinary labour because it is available at low cost as compared to skilled experienced worker. In Oman usually Non skilled labour is hired from other countries that increase the cost as compared to locally available skilled and non-skilled labour. This also justifies the shortage in availability of labour in the vicinity.

Financial: From the average index analysis related to Financial Issues contributing factors in budget overrun of projects are the 'Cash flow and financial difficulties faced by contractors' having the highest rank followed by 'Delay in payment process by owner' and 'Financial difficulties of owner' having the lowest rank causing budget overrun. Financial related issues are directly concerned with client or owner of project. Cash flow claims of contractors has to pass by consultant with approval and forwarded to owner/client for payment that causes delay in payments. Most of the time budget overrun directly hurt the overall cost of project that does cause difficulties for owners/clients to generate extra budget for project.

Contract Management: Table 5.1 shows the ranking of factors causing cost overrun due to contract management concerns. In this taxonomy, 'Poor contract management,' 'Disputes on-site', and 'Mistakes and discrepancies in contract document' are significant factors causing cost overrun in construction. Poor coordination between owner, consultant, and contractor does have significant consequences on construction projects. There have been many cases wherein everything is considered acceptable; however, the project still gets cost overrun only due to poor coordination. Dispute on sites usually occurs when unforeseen weather conditions or/and any accidents happen on site. Sometimes errors and inconsistencies in contract documents also cause not only cost overrun. However, it also causes additional work, such as not conducting geotechnical investigation on-site when making a contract, excess to the construction site, and appropriate, feasible studies of the project are the main whys and wherefores.

Design Documentation: In this category, the factors that contribute to causing cost overrun in a construction project are 'Frequent design changes, 'Impractical and complicated design,' and 'Poor design and delays in design.' Table 5.1 showing the ranking of factors based on average index analysis. Frequently design changes occur due to numerous alterations required by the owner. Impractical or/and complicated design happens due to unforeseen clumsiness conditions during the construction stage that has been hidden at the time of contract management such as seasonal or/and due to rainy weather rise and fall in underground water level, changes due plumbing and fittings. Poor design is purely the responsibility of the consultant; as a consultant must hire a team of engineers, it is also advised that a team of engineers does design the project must work on the same project until the end of the project. 


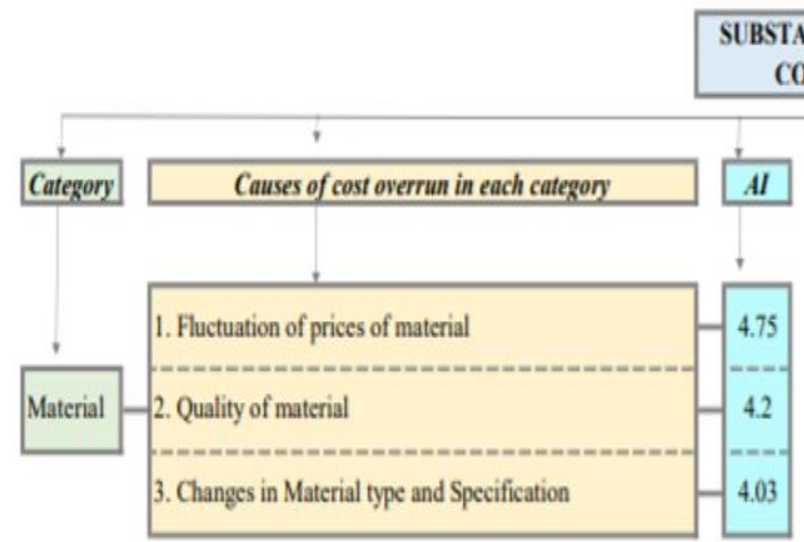

\section{COST OVERRIN}
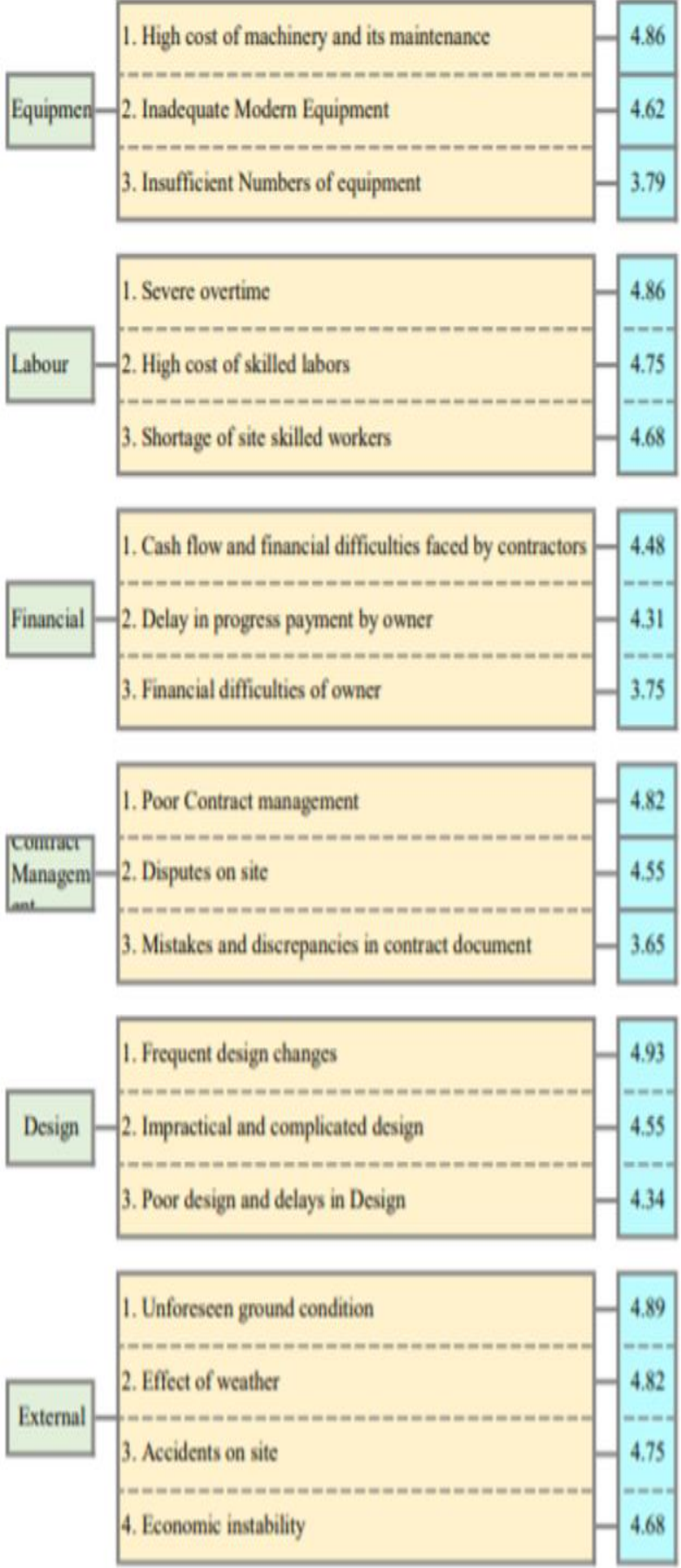
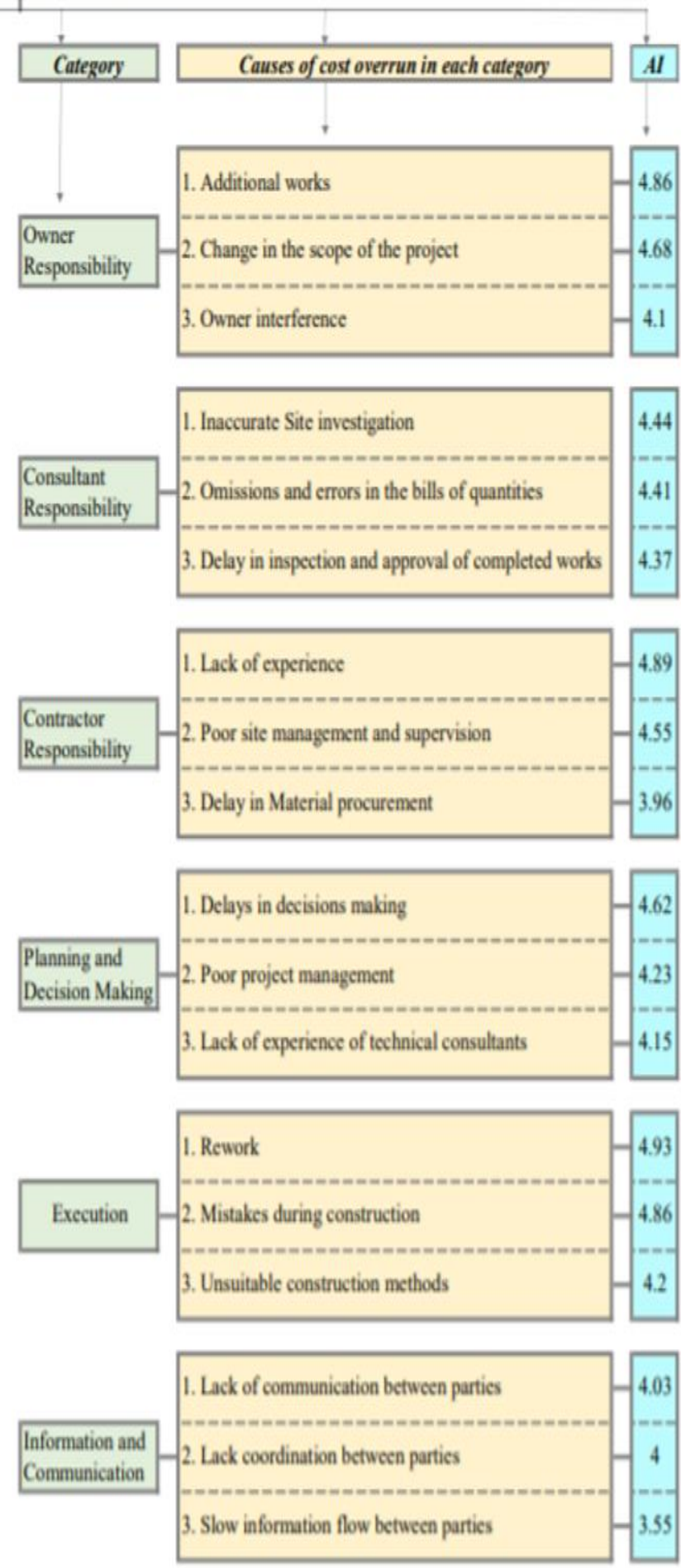
Planning and Decision Making: In this category there are 3 factors that contribute in causing cost overrun in construction project. From analysis its shows that the most important factors causing cost overrun are Delays in decisions making, Poor project management and Lack of experience of technical consultants having the lowest rank. Table 5.1 showing the ranking of factors causing cost overrun in construction project. Many essential features of the project required client approval, the late decisions during construction add cost to the project completion. Once the decision is late, the actives' chain starts, such as design changes, procurement process, and installation, all those activities get affected due to delay in decision making. The managing the project to achieve objectives requires experience from the project's management, poor management leads to poor performance, or lousy quality causes the rework, which adds burden on the project budget. Further, the consultant's staff lack of experience causes the complication in design approvals, methods of quality approvals, and on-site decisions, which contribute to project cost overrun.

Execution: In this category there are 3 factors that contribute in causing cost overrun in construction project. From analysis its shows that the most important factors causing cost overrun are Rework, Mistakes during construction and unsuitable construction methods. Table 5.1 showing the ranking of factors causing cost overrun in construction project. Rework, and mistakes are always a cause of concern in a construction project due to many causative factors such as design changes, workers' skills, inappropriate material, or unapproved material. However, those factors on cost overrun are noticeable, and special attention is required during construction to minimize the impact. In the execution category, another factor that contributes to cost overrun is the methodology of construction. The experience manager can avoid these factors by employing the experience sub-contractor with good experience in the same kind of work. The wrong construction methodology experiences expensive solutions by employing the wrong resources. The duration of activities becomes uncertain. Finally, the quality of the product may not match the specified standards.

Information and Communication: In this category top 3 factors that contribute in causing cost overrun in construction project. From analysis its shows that the most important factors causing cost overrun are Lack coordination between parties and Slow information flow between parties having the lowest rank. Table 5.1 showing the ranking of factors causing cost overrun in construction project. The project success lies in a better communication plan, making sure that the flow of information is correctly passing with an approved channel of communication to all concerned parties. Poor communication at the site may cause disbelief to either party and lead to conflict among them. The information flow from top to bottom workers will provide quick reactions to the changes and avoid rework or mistakes due to workers performing with wrong or old designs. Poor communication contributes to project cost overrun that minimizing by adopting industry standards approved by all stakeholders a communication plan.

Owner Responsibility: : In this category, the top 3 factors that contribute to causing cost overrun in the construction project. An analysis shows that the most critical factors causing cost overrun are additional works, change in the scope of the work, and owner interfaces. Any addition to the original scope or the requirement from the owner's request to project directly increases the project's cost. Further, the addition of scope during construction may require more budget than if the same scope was required during the tender stage. Similarly, any changes to the scope during construction cause cost overrun, changes during construction causes rework, sometimes abort the already executed work or demobilize the resources. Lastly, the owner interference in construction allows unnecessary barriers such as architectural approvals and mockups. The contractor cannot procure material unless the client approved the mockup and advise future courses of action to contract. That unnecessary interface from the owner adds many activities to complete the task and requires contractor efforts, consequently adding cost to the project budget.

Consultant Responsibility: In this category, the top 3 factors contribute to the cost overrun to construction projects, as shown in table 5.1. The highest score was Inaccurate Site investigation; thus, cost overrun can happen because the site's improper investigations will result in the redesign of the project elements, which will increase the project's total budget. The omissions and errors in the bill of quantity would be due to not accurate estimation. During making a bill of quantity, the errors in major elements quantity will add to the project budget. Lastly, the consultant factor for cost run is delays in inspection and approvals of completed work; the inspection process from consultant is a significant cause of concern to the contractor for their task to approve on time to utilize their resources on other similar tasks of the project. Once the process slows down the approval, it adds cost and time to the project.

Contractor Responsibility: In this category, the top 3 factors contributing to the cost overrun to construction projects are lack of experience, poor site management, supervision, and delay in procurement of material, as shown in table 5.1. The contractor personals experience is key to the project success, every project is unique, and the experienced workers help produce quality work without rework or mistakes on site. The mistake during construction requires rework, and that results in an extra workforce to complete the task, and loss of material leads to cost overrun. The poor site management and supervision factor from contractors' prospects are critical; during construction, the management role is vital to monitor the progress according to the approved baseline with quality-the poor site management results in the poor project performance. Lastly, the contractor's procurement delay is a significant cause of cost overrun; the non-availability of material at the site leads to idle the resources that mean the waste of money.

External: In this category, four factors contribute to causing cost overrun in the construction project. The analysis shows that the most critical factors causing cost overrun are Unforeseen ground condition, Effect of weather, Accidents on-site, and Economic instability, as shown in table 5.1. The unforeseen ground condition during 
construction delays design, and third-party utility diversions required ample time to get approval and add cost to the project budget. The weather conditions that were not realized during the tender impact the planning and execution of the project require a cost to mitigate climate conditions' effects. On-site accidents also impact the project's progress; if this type of event is not considered in project contingency, then add to the project cost to complete. Lastly, the economic instability factor plays an essential part in project progress; the economy's instability creates confusion to the contractor and the client for the smooth payment of the work results in slow progress and adds the project budget's cost.

\section{Conclusion}

This research has helps to identify factor causes of budget overrun in construction at Muscat, Khabourah, Bidbid, Musanah and Sohar cities in Oman. The substantial factors causing budget overrun in construction process related to Materials, Equipment, Labour, financial, Contract management, design, Owner responsibilities, consultant responsibilities, contractor responsibilities, Planning, decision making, execution, information and communication, and external have been analyzed by using average index method with client, consultant, and contractor prospective. These findings will give a better understanding to the construction industry companies regarding flaws in management and create awareness among them for undertaking future construction projects to avoid/reduce budget overrun. It is concluded that the government organizations or private firms' consultant and contractors can develop or improve legislation for construction projects based on this study to avoid budget overrun in forthcoming construction projects.

\section{References}

Aftab H. M., Ismail A. R., Abdullah M. R., Azis A. S. A, Factors affecting construction cost performance in project management projects: Case of MARA large projects. International Journal of Civil Engineering and Built Environment, 1 (1), 30-35, 2014

Alias Imran Latif, Q. B., Oman Construction Industry Prospective on Cause of Construction Material Waste. International Journal of Integrated Engineering, 12(1), 243-252, 2020

Imran Latif, Q. B. alias, Al Saadi, A. M. D., \& Abdul Rahman, I, Identification of Delay Factor in Oman Construction Industry. International Journal of Sustainable Construction Engineering and Technology, 10(1), 2019

Rahman I A, Memon A H, Abd Karim A T (2013), Examining factors affecting budget overrun of construction projects undertaken through management procurement method using PLS-SEM approach, Procedia - Social and Behavioral Sciences 107 ( 2013 ) 120-128

Abdulaziz Alghonamy, Cost Overrun in Construction Projects in Saudi Arabia: Contractors‘ Perspective, International Journal of Engineering \& Technology IJET-IJENS Vol:15 No:04, Pp 35 - 42, 2015

Reshma Mary Johnson \& Robin Itty Ipe Babu, Time and cost overruns in the UAE construction industry: a critical analysis, International Journal of Construction Management, DOI: 10.1080/15623599.2018.1484864, 2018

Memon A H, Rahman I A, Abdullah M R, Azis A A A, Factors Affecting Construction Cost in Mara Large Construction Project: Perspective of Project Management Consultant, International Journal of Sustainable Construction Engineering \& Technology Vol 1, No 2, Pp $41-54,2010$

Tariq Al Amria and Manuel Marey-Pérez, Towards a sustainable construction industry: Delays and cost overrun causes in construction projects of Oman, Journal of Project Management 5 (2020) 87-102, 2020

K. Alzebdeh*a, H.A. Bashirb and S.K. Al Siyabic, Applying Interpretive Structural Modeling to Cost Overruns in Construction Projects in the Sultanate of Oman, The Journal of Engineering Research Vol. 12, No. 1, Pp 53-68, 2015

I. Abdul Rahman, I., Memon, A.H., Abd.KArim, A, "Significant Factors Causing Cost Overruns in Large Construction Projects in Malaysia,” J. Appl. Sci., vol. 13, no. 2, pp. 286-293, 2013

Roslan N, Zainun N Y, Memon A H, Measures for Controlling Time and Cost Overrun Factors during Execution Stage, International Journal of Construction Technology and Management Vol.1, No.1, Pp 8 - 11, 2014

Ismail Abdul Rahman, Ismaaini Binti Ismail, Mustafa Musa Jaber, Risk Assessment of Time and Cost Overrun Factors throughout Construction Project Lifecycle: Pilot Study, International Journal of Engineering \& Technology, 7 (3.20), 
Pp 717-723, 2018

Aftab Hameed Memon and Ismail Abdul Rahman, SEM-PLS Analysis of Inhibiting Factors of Cost Performance for Large Construction Projects in Malaysia: Perspective of Clients and Consultants, The Scientific World Journal Volume 2014, Article ID 165158, 9 pages http://dx.doi.org/10.1155/2014/165158, 2014

Ismaaini Ismail, Aftab Hameed Memon, Ismail Abdul Rahman, Expert opinion on risk level for factors affecting time and cost overrun along the project lifecycle in Malaysian Construction Projects, International Journal of Construction Technology and Management Vol.1, No.2, Pp 10 - 15, 2014

Aftab Hameed Memon, Ismail Abdul Rahman, Analysis of Cost Overrun Factors for Small Scale Construction Projects in Malaysia Using PLS-SEM Method, Modern Applied Science; Vol. 7, No. 8, Pp 78 - 88, 2013

Jamilus Md Hussin, Ismail Abdul Rahman, Aftab Hameed Memon, The Way Forward in Sustainable Construction: Issues and Challenges, International Journal of Advances in Applied Sciences (IJAAS) Vol.2, No.1, pp. 31- 42, 2013

Ismail Abdul Rahman, 1 Aftab Hameed Memon, 2 Ade Asmi Abdul Azis and 3 Nor Hazana Abdullah, Modeling Causes of Cost Overrun in Large Construction Projects with Partial Least Square-SEM Approach: Contractor's Perspective, Research Journal of Applied Sciences, Engineering and Technology 5(6): 1963-1972, 2013

Muralidaran Ramabhadran, An Investigation into Cost Overrun in Construction Projects in United Arab Emirates, International Journal of Construction Engineering and Management, 7(1): Pp1-21, DOI: 10.5923/j.ijcem.20180701.01, 2018 